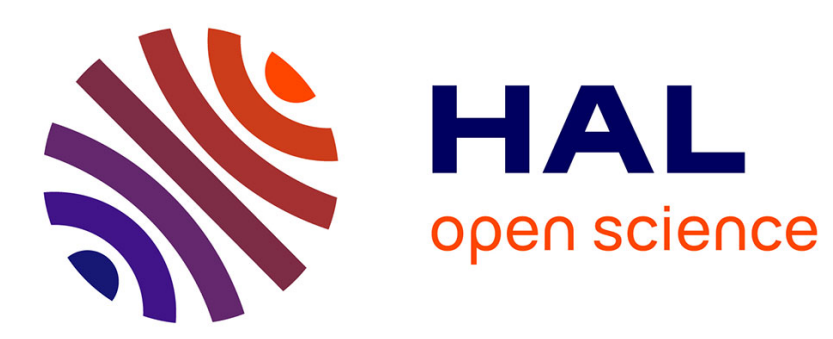

\title{
Communicating Sensory Attributes and Innovation Through Food Product Labeling
}

Caroline Lancelot Miltgen, Gaelle Pantin-Sohier, Bianca Grohmann

\section{To cite this version:}

Caroline Lancelot Miltgen, Gaelle Pantin-Sohier, Bianca Grohmann. Communicating Sensory Attributes and Innovation Through Food Product Labeling. Journal of Food Products Marketing, 2016, 22 (4), 10.1080/10454446.2014.1000435 . hal-01247599

\section{HAL Id: hal-01247599 \\ https://hal.science/hal-01247599}

Submitted on 23 Dec 2015

HAL is a multi-disciplinary open access archive for the deposit and dissemination of scientific research documents, whether they are published or not. The documents may come from teaching and research institutions in France or abroad, or from public or private research centers.
L'archive ouverte pluridisciplinaire HAL, est destinée au dépôt et à la diffusion de documents scientifiques de niveau recherche, publiés ou non, émanant des établissements d'enseignement et de recherche français ou étrangers, des laboratoires publics ou privés. 


\section{Communicating Sensory Attributes and Innovation Through Food Product Labeling}

Caroline Lancelot Miltgen, Gaëlle Pantin Sohier \& Bianca Grohmann

To cite this article: Caroline Lancelot Miltgen, Gaëlle Pantin Sohier \& Bianca Grohmann (2015):

Communicating Sensory Attributes and Innovation through Food Product Labeling, Journal of Food Products Marketing, DOI: 10.1080/10454446.2014.1000435 


\title{
Communicating Sensory Attributes and Innovation through Food Product Labeling
}

\begin{abstract}
Purpose - This research explores the influence of informational stimuli on product sensory expectations and perceived newness of the product.

Design/methodology/approach - Two experiments examine to what extent consumers use product typicality, graphical representations, and package typicality in evaluating new products.

Findings - Study 1 finds that (1) a typical flavor induces more positive expectations of pleasantness, taste, color, and smell, and (2) the presence of graphic representation on product labels increases perceived pleasantness, but does not affect sensory expectations. Study 2 indicates that the product seems newer in the absence of a package (label-only condition) but when the product packaging is presented, an atypical package conveys more newness than a typical package.

Originality/value - These results provide practical guidelines for the design and introduction of innovative food products, which can help practitioners use appropriate communication cues to evoke positive sensory expectations and anticipated pleasantness.
\end{abstract}

Keywords: Communication of sensory information; consumer expectations; new food products; packaging; sensory attributes 


\section{Communicating Sensory Attributes and Innovation through Food Product Labeling}

\section{Introduction}

At the point of purchase, informational stimuli such as product labels and packaging play a fundamental role in consumers' purchasing decisions, especially for new food products. Consumers learn about new products in many ways (Hoeffler, 2003), including categorybased learning, analogies, and mental simulations. Understanding how informational stimuli affect consumer perceptions, evaluations, and behaviors has both theoretical and managerial implications (Imram, 1999).

This research builds on cognitive psychology research pertaining to the role of typicality and visual information to explore the role of labels and packaging as antecedents of taste and pleasantness perceptions for a new food product. It examines the influence of informational stimuli (i.e., labels, packaging) on expectations about a new food product (flavored cider) and focuses on the influence of the typicality of the flavor associated with the product, the type of packaging, and the presence/absence of graphical representations on the label on consumers' sensory expectations, evaluations of pleasantness, and perceived newness. This research contributes to theory and managerial practice by identifying product characteristics that convey the newness of the product and by testing to what extent images and colors and packaging — which are often the first cues consumers are exposed to-determine consumers' new product-related beliefs.

\section{Antecedents of Expected Sensory Perception and Pleasantness}

\subsection{Product typicality}

When consumers consider a food product, its sensory properties - appearance (sight), smell (olfaction), texture (vision, touch, proprioception), and to a lesser extent sound (hearing) influence evaluations (Delwiche, 2004). The information provided by sensory properties help consumers categorize the product, form expectations about it, and anticipate pleasure based 
on previous experiences. For food products, taste is an important evaluation criterion. To anticipate a new product's taste, consumers use past experiences — if available —or form inferences based on the product's extrinsic features (Pinson, 1986). In the case of new products, consumers initially have to rely on extrinsic cues such as visual information on labels and packaging to evaluate the product. Based on extrinsic cues, consumers develop sensory expectations and expectations about the potential pleasure of ingesting the product. Thus, extrinsic cues (e.g., price, brand, labels, packaging) rather than the product itself initially influence consumers' beliefs about a product. Extrinsic cues generate cognitive reactions — such as sensory expectations (e.g., about product taste)—or emotional responses highlighted by hedonic expectations (e.g., pleasure expected from consuming a food product). For example, color influences predictions about the intensity of the taste and smell of beverages (Franck et al., 1989; Pangborn, 1960; Pangborn and Hansen, 1962; Zellner and Durlach, 2003; Zellner and Kautz, 1990). For food, the flavor associated with the product also contributes information, such that familiarity with the flavor and its congruence with the specific food item influence evaluations (Porcherot, 1996). Flavor familiarity thus has a significant effect on the acceptability of food products (Stalleberg-White and Pliner, 1999), especially for innovations. Aromatic (i.e., smell) complexity also may affect palatability, according to people's experience and the novelty of the stimulus, but this component has not been studied as much due to its methodological challenges (Levy et al., 2006; Sulmont-Rossé et al., 2008).

This research considers the influence of the product's flavor typicality on consumers' expectations about the odor, color, and taste of a new product, as well as the degree of anticipated pleasantness of the product. Typicality describes the degree to which a product is representative of a category, and is based on prior learning experiences and associations 
(Heckler and Childers, 1992). Atypical flavors are more difficult to categorize, and should therefore lead to more negative sensory and pleasantness expectations.

H1: For a new food product, information regarding a typical (vs. atypical) flavor prompts more positive expectations of (a) pleasantness, (b) taste, (c) color, and (d) smell.

\subsection{Product information}

Product information should be presented in a manner that increases the ease of comprehension, such as by using "symbols which quickly convey the concept" (Bettman, 1986; p.15). Dual processing theory suggests that when an icon reinforces a verbal statement, the two components combine to improve overall understanding and recall. Heckler and Childers (1992), for example, find that memory improves when a message includes a congruent (i.e., both relevant and expected in the context) image. The influence of descriptions on product labels has been investigated, but never explicitly for innovative products. For example, diet and light labels significantly influence sales and sensory evaluations of food products (Wansink et al., 2004), though the influence varies according to the hedonic (e.g. a dessert) or functional (e.g. an entree) nature of the food product. Wansink, Van Ittersum, and Painter (2005) also demonstrate that a restaurant menu that offers evocative, descriptive suggestions (e.g., "delicious fish filet, savory Italian style”) leads consumers to consider the food as more appetizing, tasty, and calorie-laden, compared to the use of simple terms (e.g., "fish filet"). These effects are not limited to sensory descriptions: Keller and colleagues (1997) show that nutrient levels listed in Nutrition Facts panels on the back of packages mitigate the effect of nutrition claims on the front of the packages on consumers' overall product evaluations and purchase intentions. This suggests that consumers do not rely primarily on nutrition claims to make their overall nutrition and 
product evaluations, if other nutritional information is readily available (Ford et al., 1996; Keller et al., 1997).

In marketing communications and packaging, visual elements often dominate verbal elements in their effect on information processing, due to their vividness and ability to attract attention (Mitchell, 1986; Paivio and Csapo, 1973). Images are easy to recognize and remember (Childers and Houston, 1984), and have a profound impact on consumer perceptions and judgment (Holbrook and Moore, 1981). Graphical representations exert significant, long-term effects on product beliefs and purchase intentions (Bone and France, 2001). The current research tests whether graphical representations (presence vs. absence of ingredient images) influence consumers' sensory and pleasantness expectations about a new food product.

$\mathrm{H} 2$ : The presence (vs. absence) of a visual representation of product ingredients on product labels results in more positive expectations about (a) pleasantness, (b) taste, (c) color, and (d) smell.

Study 1 examines the impact of flavor typicality (H1) and graphical representations of ingredients (H2) on consumers' sensory and pleasantness expectations. This research further investigates the influence of package typicality on consumer responses to a new product. The conceptual background is discussed next.

\section{Effects of Package Typicality on Sensory Expectations and Perceived Newness}

\subsection{Package typicality, sensory and pleasantness expectations}

Research acknowledges the importance of package design (Bloch, 1995; Garber et al., 2000; Hertenstein et al., 2005; Rettie and Brewer, 2000; Roehm and Roehm Jr, 2010; Schoormans and Robben, 1997; Veryzer, 1999), because package design distinguishes brand offerings and induces favorable impressions (Berkowitz, 1987; Henderson et al., 2003; Schmitt and Simonson, 1997). Decisions about package typicality are critical for managers, and include 
considerations of brand image associations (e.g., Coca-Cola bottle) and consumer perceptions. For example, packaging that appears larger tends to be purchased more often (Raghubir and Krischna, 1999). During their in-store shopping, consumers exert little effort to find volume information on package labels (Cole and Balasubramanian, 1993). Furthermore, packages which attract more attention are also perceived to contain more volume of a product than similarly sized packages that attract less attention. The disparity in the level of attention creates a mental "contamination" of volume assessment (Folkes and Matta, 2004). Thus, packaging enables managers to alter consumers' product perceptions without substantively changing the product (Bloch, 1995; Wansink, 1996).

Various marketing communication cues (labels and package typicality for example in terms of shape) may be influential and include information about product typicality and graphical representations on labels. Marketers should convey consistent messages across different elements of the communication mix, whether in advertisements, in-store promotions, or packaging (Shimp, 2010). Cue consistency has important implications for brand equity and sales (Duncan and Everett, 1993; Low, 2000; McArthur and Griffin, 1997). Garretson and Burton (2005) examine strategic combinations of advertising cues, including spokespersons and verbal attributes in integrated marketing communications (IMC) campaigns and find empirical evidence of the benefits of including consistent spokes characters throughout IMC campaigns, including favorable attitudes toward a brand. The current research examines package typicality and its impact on consumers' perceptions of sensory attributes and pleasantness. In light of the evidence regarding the positive impact of cue consistency, it includes package typicality (label only, bottle, can) along with ingredient typicality (caramel vs. black currant) and ingredient information (absence vs. presence of graphical representation) as experimental factors to explore potential interaction effects. In line with the literature on typicality, the following hypotheses arise: 
H3: A typical package increases expectations of (a) pleasantness, (b) taste, (c) color, and (d) smell compared to an atypical package, and even more so compared to a label only.

\subsection{Package typicality and perceived newness of the product}

Consumers are generally ambivalent toward product innovativeness, especially in the food sector, and may wish to both approach (neophilia) and avoid (neophobia) new food products. The opposing tendencies driven by curiosity and fear result in consumer preferences for new products with moderate levels of innovation (Spielberger et al., 1981; Zuckerman, 1991). Folkes and Matta (2004) suggest that a package that attracts more consumer attention (less typical) appears newer than a similarly sized package than attracts less attention (more typical). The current research considers cider as the focal product category. As cider is usually packaged in a bottle when sold in supermarkets, local street markets and wine merchants, the bottle is considered as the more typical package. A can (i.e., atypical package) should thus attract more attention than a bottle, because of its novelty (Johnson et al., 1990).

Regardless of the packaging, an atypical flavor should also attract more attention. Thus perceived newness should be higher when the consumer sees only the label and not the product package. If consumers judge a product based on only its label, information on the label receives undivided attention (i.e., is not directed toward package typicality) and thus highlights ingredients and flavors. However, product packaging should reinforce product newness if that packaging itself is atypical, or diminish perceived product newness if packaging is typical.

H4: The perceived newness of a new food product is higher when consumers only see the label rather than the product packaging $(\mathrm{H} 4 \mathrm{a})$. Perceived newness is higher when the product is contained in an atypical packaging than when it is contained in a typical package (H4b). 
Radford and Bloch (2011) underlined that the connection between product innovation and visual design remains understudied despite being recognized as an important issue by innovation researchers (Hauser et al., 2006) and the growing interest in consumer reactions to design generally (e.g. Bloch, 1995, Leder et al., 2004; Veryzer and Hutchinson, 1998). Study 2 examines the effect of packaging typicality on sensory expectations and perceived newness (H3 and $\mathrm{H} 4)$ in order to bring new insight to the product innovation and visual design literatures.

\section{Study 1}

This experiment investigates how the typicality in flavors and graphical information influence product evaluations and expected liking in the absence of an actual taste experience.

\subsection{Stimuli and procedure}

Stimuli consisted of labels for an alcoholic cider beverage with a fictitious brand name. Research using fictitious brands contributes more research knowledge (Campbell and Keller, 2003) because fictitious brands serve as novel brand, and findings therefore extend to prototype development scenarios. Product typicality was manipulated through product flavor: black currant (typical) and caramel (atypical). The ingredients were clearly specified on the labels by flavor name and associated colors (purple, yellow-orange; see Appendix A). Furthermore, graphical representation of ingredients (bunch of black currants, caramel chunks) was present or absent. The experiment thus employed a 2 (ingredient typicality: typical, atypical) $\times 2$ (graphic representation: absent, present) between-participants design.

In an online survey, 460 French university students (20.5 years of age on average $\left.{ }^{1}\right)$ were $^{2}$ contacted via e-mails that contained a link to the online questionnaire. They were asked to evaluate a new beverage in advance of its market launch. Cider was selected because it is a popular alternative drink for younger consumers in search of novelty and contains less alcohol

\footnotetext{
${ }^{1}$ Although the legal drinking age is 21 years in the United States, it is only 18 in the country where the study was run. The students surveyed would thus legally be able to have prior experiences with alcoholic ciders and to give their anticipated reactions to a new alcoholic beverage such as the one proposed here.
} 
than other drink mixes. It also requires new consumption and purchasing habits without involving a new production method.

Participants were randomly assigned to one of the conditions and first saw an image of the four experimental stimuli (product labels). Participants then answered five-point Likert-scales (anchored fully disagree/fully agree) measuring sensory expectations (taste, smell, color; two items each) and pleasantness (two items). Three items measured the perceived typicality of the flavor ("This aroma accompanies the cider well", "It seems to be a good mixture", "The flavor matches the product category") and served as manipulation checks.

\subsection{Results}

Table 1 summarizes the MANOVA results.

Insert Table 1 about here

In support of H1, typical ingredients (i.e., black currant) induce more positive product expectations in terms of pleasantness, taste, color and smell. Specifically, the typical product was perceived as more tangy (3.45 vs. 3.04, $p=.000)$ and fruitier (4.02 vs. 2.92, $p=.000)$, with an original color (3.57 vs. $3.09, p=.000)$ and a pleasant smell (3.04 vs. $2.85, p=.032)$, and it was expected to be more agreeable to drink (3.04 vs. $2.63, p=.000)$. In contrast, the atypical product appeared more disagreeable (3.04 vs. 2.70, $p=.000)$ and sickening (3.54 vs. $2.97, p=.000)$.

The presence of a visual representation of the flavor on the label induced more positive expectations about product pleasantness. The typical product was expected to be more pleasant to drink (2.92 vs. $2.72, p=.041)$ and less sickening (3.16 vs. $3.40, p=.033)$, in support of H2a. However, the presence or absence of a visual representation did not affect disagreeable taste (2.96 vs. $2.81, p=.146)$, different smell (2.90 vs. $2.98, p=.413)$, and color originality (3.31 vs. 3.34, $p=.803$ ) expectations. Visual representation thus did not influence taste, color, and smell expectations. $\mathrm{H} 2 \mathrm{~b}-\mathrm{H} 2 \mathrm{~d}$ were not supported. 
Finally, a significant interaction effect emerged between flavor typicality and the absence/presence of graphical representation of the flavor with regard to taste expectations: the typical product and presence of the ingredient image on the label resulted in fruitier product expectations (4.16), compared to absence of ingredient image $(3.81, \mathrm{p}=0.011)$.

This experiment supports the predicted effect of product typicality on consumers' sensory expectations. As hypothesized, consumers appear to prefer a typical versus atypical/moderately atypical flavor, confirming a preference for the norm (Campbell and Goodstein, 2001). In addition, the presence of a visual representation on the label induced more positive expectations about the pleasantness of the product confirming that graphical representations exert a significant effect on consumers' product beliefs (Bone and France 2001). The difference between this study and earlier work is that it considers the joint effects of product typicality and presence/absence of a visual representation on taste expectations and pleasantness.

\section{Study 2}

Study 1 focused on the impact of informational stimuli (information regarding product typicality and visual representation) on consumer expectations. To examine the effect of package typicality on expectations and product newness perceptions ( $\mathrm{H} 3$ and $\mathrm{H} 4)$, a second study was conducted. Cider again served as the focal product category.

\subsection{Stimuli and procedure}

Study 2 uses a 2 (ingredient typicality: typical, atypical) $\times 2$ (graphic representation: present, absent) $\times 3$ (package typicality: label-only, typical [bottle] versus atypical [can] package) between-participants design. To control for possible confounds, both packages were depicted in the same material (metal). A three-item manipulation check for product typicality confirmed that black currant cider more typical than caramel flavored cider (3.40 vs. $2.91 ; \mathrm{F}=$ $29,742 ; p=.001)$. 
The questionnaire was completed by 383 students and consumers under 35 years of age (92.4\% younger than 24 years, $6.3 \%$ between $25-34$ years; $98.4 \%$ students; $55.5 \%$ women), who represent the main target market for alcoholic ciders. After being randomly assigned to one of the experimental conditions, participants rated sensory expectations (taste, smell, color) on two items each, and expected pleasantness on four items. Perceived newness was measured on two items (“original," "inspired"). Finally, participants reported their usual cider consumption habits.

\subsection{Results}

An exploratory factor analysis for the pleasantness scale confirmed a single dimension and satisfactory reliability $(\alpha=.79)$. The results shown in Tables 2 and 3 summarize the results of this study.

\section{Insert Tables 2 and 3 about here}

The typical packaging increased perceived pleasantness compared to label-only and even more so compared to the atypical packaging (3.30 vs. 3.16 vs. $2.75, p=.000$ ), supporting H3a. However, H3b was not supported in terms of both fruity taste $(p=.499)$ and disagreeable taste $(p=.152)$. The effect of the package on color perceptions was only partially supported $(\mathrm{H} 3 \mathrm{c})$ in that respondents perceived color as more original in the label-only and atypical packaging conditions (3.57 vs. 3.48 vs. $3.33, p=.024)$. Color was perceived as more distant for the atypical packaging, compared to label-only and typical packaging. Similarly, the effect of packaging on smell perceptions was only partially supported (H3d): pleasant smell expectations were higher for the typical packaging compared to the label-only or atypical packaging (3.40 vs. 3.25 vs. $2.96, p=.000)$. In contrast, the atypical packaging resulted in higher scores on "special smell" compared to the label-only or typical packaging $(p=.450)$. 
Newness was perceived as higher in the label-only version, which supports H4a. The atypical packaging generated more perceived newness on the item "imaginative", but the typical package was rated higher on the item "original”. H4b was therefore partially supported.

This study finds several interaction effects of package typicality and graphical representation on color expectation ("original color"), product originality, and pleasantness about the product (pleasantness; see Appendix B): Color expectation differed across graphical representation conditions in the label-only condition, but not in the atypical packaging condition. For the typical package, color was expected to be more original in absence of the ingredient whereas the contrary holds for the label-only condition.

The results for the product global originality item suggest that the typical package with a graphical representation of ingredients was expected to be less original. The product appeared more original for label-only combined with graphical representation of ingredients or for the typical package without graphical representation. Finally, in terms of pleasantness evaluations, the typical packaging without graphic representation scored highest, whereas the atypical package without graphic representation scored lowest.

This research focuses on (visual) informational stimuli as determinants of sensory expectations, pleasantness, and newness perceptions. The interaction effects shed more light on how consumers react to an atypical (new) product. For the typical package, color and product are expected to be more original in the absence of graphical representation of ingredients, which means that graphical representation is not useful in conveying originality. For managers, it is important to consider the need for and impact of graphical representation on sensory expectations and perception of newness. 


\section{General Discussion}

\subsection{Implications}

This research demonstrates that design elements can be used strategically to create favorable expectation of food products in the absence of taste experience. People infer taste, color, and quality of a new product on the basis of extrinsic cues which are under marketers' control. For example, the combination of a fruit-derived beverage (cider) with another, typical fruit ingredient (black currant) generated more positive expectations than a combination with an atypical ingredient (caramel). Respondents predicted that caramel cider would be sweeter, more sickening, and disagreeable in its aftertaste, whereas black currant cider was expected to be pleasant to drink. Sensory product evaluations depend significantly on ingredient combinations, and this research supports that typicality significantly influences consumers' evaluations, including their taste perceptions and anticipation of pleasantness.

Furthermore, graphic representation provided on product labels influences consumers' taste and pleasantness predictions. Graphic representation of ingredients made the new product more pleasant and less sickening, maybe because it diminish perceived risk. The current empirical validation of the relation between informational cues about the product and sensory perceptions provides an important theoretical contribution regarding sensory interactions in the food sector.

\subsection{Theoretical contributions}

This research differs from previous investigations in that it examines several informational cues (product typicality, graphic representation, package typicality) that affect various dimensions of sensory expectations. Package typicality, for example, affects product evaluation, including expected pleasantness. Packaging further affects the perceived sweetness or acidity of its contents, which indicates that consumers infer gustatory beliefs from extrinsic cues. This research thus extends the literature on the impact of packaging 
variables on consumer reactions. Whereas previous studies focused mainly on the shape or color of products, sensory marketing demands more complex approaches that combine a greater number of variables. Manipulation of various cues therefore increases current knowledge of sensory interactions among product, labels, and packaging. This research complement work by Rettie and Brewer (2000) regarding the quantity and location of information contained on packages. The presence of graphical representations as indicators of flavor influenced taste expectations; the presence/absence of graphical representations affect expected taste particularly strongly when ingredients are typical of the product. For example, an image of black currants made the cider seem less sweet-perhaps because it conjured the astringent taste of black currents to a greater degree. However, an image of caramel chunks did not influence sweetness intensity ratings.

This research speaks to the potential impact of the location of the product image, such that images on the front label may influence consumers' perceptions and evaluations to a greater or lesser extent depending on their location (Deng and Kahn, 2009). Further research can pursue effects of the location of graphical ingredient representations beyond the current focus on presence or absence. Researchers might also further investigate to what extent graphical ingredient representations reduce product neophobia.

From a methodological point of view, this research builds on previous packaging design studies by analyzing several variables simultaneously using a realistic depiction of the package (designed in collaboration with a food industry innovation project group and created by a computer graphic designer). Previous studies often use black-and-white drawings of objects (Veryzer and Hutchinson, 1998) or unaltered photographs (Hekkert, Snelders and Van Wierigen, 2003). In this research, realistic designs allowed participants to evaluate an actual prototype as a potential entrant to the beverage market. 


\subsection{Implications for food marketers}

Finally, from a managerial point of view, this research offers insight regarding the design of new food products and provides guidelines helpful in the selection of suitable flavors, labels, and packaging. Typicality, graphical representation, and packaging were influential factors in consumers' pleasantness and sensory perceptions. These factors also changed the perceived taste intensity of the product. Graphic representation of sensory components influenced product evaluations and acceptability, which suggests new avenues for segmentation and positioning in the food industry. In practice, graphic representations may be particularly useful in conveying atypical taste combinations, which increases the acceptability of potential line extensions and encourages development of concepts directly linked to flavoring.

\subsection{Limitations and future research}

This research has several limitations that could open the door to further research. First, the studies did not account for several variables that could influence beliefs and evaluations of products, such as the brand name or typeface used on the label, as well as mediating variables such as perceived authenticity. The typography could be a particularly interesting variable to manipulate, in that certain fonts might be more appropriate for innovations, depending on the product category. The use of certain typographies likely creates greater congruence with an innovative connotation, as well as increases the significance of the social representation of the product for the consumer.

Secondly, Mueller, Lockshin, and Louviere (2009) recommend caution when using direct measures with visual packaging attributes, because their comparison to indirect discrete choice experiments finds a greater impact in discrete choice experiment, as well as significant preference heterogeneity. Further research therefore could therefore replicate the studies reported herein using this measurement method. In this sense, it seems relevant to discover if 
all the elements have effects on actual behaviors, such as purchases and price evaluations. Jaeger and Harker (2005) find that consumers are ready to pay twice as much for a kiwi with pink flesh, and two and half times more if the communication indicates the kiwi has not been genetically modified. Thus, product color, perceived newness, and informational stimuli all should have significant impacts on the price consumers are willing to pay.

Thirdly, further research should consider potential moderators, such as consumers' desire for food variety (Van Trijp and Steenkamp, 1992) or the need to be unique (Tian, Bearden and Hunter, 2001). Consumers with greater variety seeking tendencies are more susceptible to accept innovations, and the need to be unique might lead a consumer to buy innovative and surprising products (Irmak, Vallen and Sen 2010).

Finally, it would be interesting to advance the analysis by combining this test of sensory evaluations based on extrinsic attributes of the product with a gustative evaluation that is based on the actual taste properties of the food product. Such studies could help delineate various perceptions and outline the reasons for confirmed or rejected expectations, which likely have correlative impacts on satisfaction. 


\section{References}

Berkowitz, M. (1987), “Product shape as a design innovation strategy”, Journal of Product Innovation and Management, Vol. 4 no. 4, pp. 274-283.

Bettman, J. R. (1986), “Consumer psychology”, Annual Review of Psychology, Vol. 37, pp. 257-89.

Bone, P.F., and France, K.R. (2001), "Package graphics and consumer product beliefs", Journal of Business and Psychology, Vol. 15 No. 3, pp. 467-489.

Bloch, P.H. (1995), "Seeking the ideal form: product design and consumer response”, Journal of Marketing, Vol. 59 No. 3, pp. 16-29.

Campbell, M.C., and Goodstein, R.C. (2001), “The moderating effect of perceived risk on consumer's evaluation of product incongruity: preference for the norm", Journal of Consumer Research, Vol. 28 No. 3, pp. 439-449.

Campbell, M.C., and Keller K.L. (2003), “Brand familiarity and advertising repetition effects", Journal of Consumer Research, Vol. 30 No. 2, pp. 292-304.

Childers, T.L., and Houston, M.J. (1984), “Conditions for a picture-superiority effects in consumer memory", Journal of Consumer Research, Vol. 11 No. 2, pp. 643-654.

Childers, T.L., Houston, M.J., and Heckler, S.E. (1985), "Measurement of individual differences in visual versus verbal information processing", Journal of Consumer Research, Vol. 12 No. 2, pp. 125-134.

Cole, C.A., and Balasubramanian, S.K. (1993), “Age differences in consumers' search for information: Public policy implications," Journal of Consumer Research, Vol. 20 No. 1, pp. 157-169.

Delwiche, J. (2004), “The impact of perceptual interactions on perceived flavor”, Food Quality and Preference, Vol. 15, pp. 137-146.

Deng, X., and Kahn, B.E. (2009), "Is your product on the right side? The location effect on 
perceived product heaviness and package evaluation", Journal of Marketing Research, Vol. 46 No. 6, pp. 725-738.

Duncan, T., and Everett, S. (1993), “Client perceptions of integrated marketing communications", Journal of Advertising Research, Vol. 33 No. 3, pp. 30-39.

Folkes, V., and Matta S. (2004), “The e ffect of package shape on consumers' juudgments of product volume: Attention as a mental contaminant", Journal of Consumer Research, Vol. 31 No. 2, pp. 390-401

Ford, G.T., Hastak, M., Mitra, A., and Ringold, D.J. (1996), “Can consumers interpret nutrition information in the presence of a health claim? A laboratory investigation", Journal of Public Policy and Marketing, Vol. 15 No. 1, pp. 16-27.

Franck, R.A., Ducheny K., and Mize S.J.S. (1989), "Strawberry odor, but not red color, enhances the sweetness of sucrose solutions”, Chemical Senses, Vol. 14, pp. 371-377.

Garber, L.L., Burke, R.R., and Jones, J.M. (2000), “The role of package color in consumer purchase consideration and choice”, Marketing Science Institute Report, No. 00-104.

Garretson, J.A., and Burton, S. (2005), “The role of spokescharacters as advertisement and package cues in integrated marketing communications", Journal of Marketing, Vol. 64 No. 4, pp. 118-132.

Goldsmith, R.E., and Hofacker, C.F. (1991), “Measuring consumer innovativeness”, Journal of the Academy of Marketing Science, Vol. 19 No. 3, pp. 209-221.

Hauser, J., Tellis, G.J., and Griffin A. (2006), "Research on innovation: A review and agenda for Marketing Science”, Marketing Science, Vol. 25 No. 6, pp. 687-717.

Heckler, S.E., and Childers T.L. (1992), “The role of expectancy and relevancy in memory for verbal and visual information: what is incongruency?", Journal of Consumer Research, Vol. 18 No. 4, pp. 475-492.

Henderson, P.W., Cote, J.A., Leong, S.M., and Schmitt B. (2003), "Building strong brands 
in Asia: Selecting the visual components of i mage to maximize brand strength", International Journal of Research in Marketing, Vol. 20 No. 4, pp. 297-313.

Hertenstein, J. H., Platt, M.B., and Veryzer, R.W. (2005), “The impact of design effectiveness on corporate financial performance", Journal of Product Innovation Management, Vol. 22 No. 1, pp. 3-21.

Hekkert, P., Snelders, D., and Van Wierigen P. (2003), "Most advanced, yet acceptable: typicality and novelty as joint predictors of aesthetic preference in industrial design", British Journal of Psychology, Vol. 94 No. 1, pp. 111-124.

Hoeffler, S. (2003), "Measuring preferences for really new products”, Journal of Marketing Research, Vol. 40 No. 4, pp. 406-420.

Holbrook, M.B., and Moore, W.L. (1981), "Feature interactions in consumer judgments of verbal versus pictured presentations", Journal of Consumer Research, Vol. 8 No. 1, pp. 103113.

Hutchings, J.B. (1999), Food colour and appearance (2nd ed.), Gaithersburg: Aspen Publishers.

Imram, N. (1999), "The role of visual cues in consumer perception and acceptance of food product", Nutrition and Food Science, Vol. 99 No. 5, pp. 224-228.

Irmak, C., Vallen, B., and Sen S. (2010), "You like what I like, but I don't like what you like: uniqueness motivations in product preferences", Journal of Consumer Research, Vol. 37 No. 3, pp. 443-455.

Jaeger, S.R., and Hacker, F.R. (2005), "Consumer evaluation of novel kiwifruit: willingness to pay”, Journal of the Science of Food and Agriculture, Vol. 85 No. 15, pp. 2519-2526.

Johnson, W.A., Hawley, K.J., Plewe, S.H., Elliott, J.M.G., and De Witt, M.J. (1990), “Attention capture by novel stimuli”, Journal of Experimental Psychology: General, Vol 119, pp. 397-411 
Keller, S.B., Landry, M., Olson J., Velliquette A.M., Burton S., and Andrews J.C. (1997), "The effects of nutrition package claims, nutrition facts panels, and motivation to p rocess nutrition information on consumer product e valuations", Journal of Public Policy and Marketing, Vol. 16 No. 2, pp. 256-269.

Leder, H., Belke, B., Oeberst, A., and Augustin, D. (2004), “A model of aesthetic appreciation and aesthetic judgments”, British Journal of Psychology, Vol. 95 No. 4, pp. 489-508.

Levy, C.M., MacRae, A., and Koester, E.P. (2006), "Perceived stimulus complexity and food preference development”, Acta Psychologica, Vol. 123 No. 3, pp. 394-413.

Low, G.S. (2000), “Correlates of integrated marketing communications”, Journal of Advertising Research, Vol. 40 No. 3, pp. 27-39.

McArthur, D.N., and Griffin, T. (1997), “A marketing management view of integrated marketing communications”, Journal of Advertising Research, Vol. 37 No. 5, pp. 19-26.

Mitchell, A. (1986), "The effects of verbal versus visual components of advertisements on brand attitudes and attitude toward the advertisement", Journal of Consumer Research, Vol. 13 No. 1, pp. 12-24.

Mueller, S., Lockshin, L., and Louviere, L. (2010), "What you see may not be what you get: Asking consumers what matters may not reflect what they choose", Marketing Letters, Vol. 21 No. 4, pp. $335-350$

Paivio, A., and Csapo, K. ( 1973), "Picture superiority in free recall imagery or dual coding?", Cognitive Psychology, Vol. 5 No. 2, pp. 176-206.

Pangborn, R.M. (1960), "Influence of color on the discrimination of sweetness", American Journal of Psychology, Vol. 73 No. 2, pp. 229-238.

Pangborn, R.M., and Hansen, B. (1962), “The influence of color on discrimination of sweetness and sourness in pear nectar", American Journal of Psychology, Vol. 76 No. 2, pp. 
315-317.

Pinson, C. (1986), “An implicit product theory approach to consumers inferential judgments about products", International Journal of Research in Marketing, Vol. 3 No. 1, pp. 19-38.

Porcherot, C. (1996), Contribution à la mesure de la familiarité et de la complexité d'arômes alimentaires. Pertinence de ces concepts pour expliquer les préférences des consommateurs, Université de Bourgogne ENSBANA.

Radford, S.K., and Bloch, P.H. (2011), "Liking innovation to design: consumer responses to visual product newness", Journal of Product Innovation Management, Vol. 28 No. 1, pp. 208-220.

Raghubir, P., and Krishna, A. ( 1999), "Vital d imensions in volume perception: Can the eye fool the stomach?" Journal of Marketing Research, Vol. 36 No. 3, pp. 313-26.

Rettie, R., and Brewer, C. (2000), “The verbal and visual c omponents of package design”, Journal of Product and Brand Management, Vol. 9 No. 1, pp. 56-70.

Roehm, M.L., and Roehm, H.A. Jr (2010), “The relationship between packaging uniformity and variety seeking”, Psychology and Marketing, Vol. 27 No. 12, pp. 1122-1133.

Schmitt, B.H., and Simonson, A. (1997), Marketing aesthetics: the strategic management of branding, identity and image, New York: The Free Press.

Schoormans, J.P.L., and Robben, H.S.J. (1997), “The effect of new package on product attention, categorization and evaluation”, Journal of Economic Psychology, Vol. 18, 271287.

Shimp, T.A. (2010), Advertising, Promotion, and Other Aspects of Integrated Marketing Communications (8th edition). Cincinnati, Ohio: South-Western : Cengage Learning.

Sojka, J.Z., and Giese J.L. (2001), "The influence of personality traits on the processing of visual and verbal information”, Marketing Letters, Vol. 12 No. 1, pp. 91-106.

Spielberger, C.D., Peters, R.A., and Frain, F. (1981), "Curiosity and anxiety”, In H.G. 
Voss and H. Keller (Eds.). Curiosity research: Basic concepts and results. Weinheim, DE: Beltz.

Sulmont-Rossé, C., Chabanet, C., Issanchou, S., and Köster, E.P. ( 2008), "Impact of the arousal potential of uncommon drinks on the repeated exposure effect", Food Quality and Preference, Vol. 19 No. 4, pp. 412-420.

Tian, T.K., Bearden, W.O., and Hunter, G.L. (2001), “Consumer's need for uniqueness: scale development and validation", Journal of Consumer Research, Vol. 28 No. 1, pp. 5066.

Van Trijp, H.C.M., and Steenkamp, J.B.E.M. (1992), “Consumers' variety seeking tendency with respect to foods, measurement and managerial implications", European Review of Agricultural Economics, Vol. 19, pp. 181-195.

Veryzer, R.W. Jr (1998), “Key factors affecting customers' evaluation of discontinuous new products”, Journal of Product Innovation Management, Vol. 15 No. 2, pp. 136-150.

Veryzer, R.W. Jr (1999), “A nonconscious processing explanation of consumer response to product design”, Psychology and Marketing, Vol. 16 No. 6, pp. 497-522.

Veryzer R.W. Jr, and Hutchinson, J.W. (1998), "The influence of unity and prototypicality on aesthetic responses to new product designs", Journal of Consumer Research, Vol. 24 No. 4, pp. 374-394.

Wansink, B. (1996), “Can package size accelerate usage volume?” Journal of Marketing, Vol. 60 No. 3, pp. 1-14.

Wansink, B., Van Ittersum, K., and Painter, J.E. (2004), "How diet and health labels influence taste and satiation”, Journal of Food Science, Vol. 69 No. 9, pp. 340-346.

Wansink, B., Van Ittersum, K., and Painter, J.E. (2005), "How descriptive food names bias sensory perceptions in restaurants”, Food Quality and Preferences, Vol. 16, pp. 393-400.

Zellner, D.A., and Durlach, P. (2003), "Effects of color on expected and experienced 
Refreshment, Intensity, and liking of beverages", The American Journal of Psychology, Vol. 116 No. 4, pp. 633-647.

Zellner, D.A., and Kautz, M.A. (1990), “Color affects perceived odor intensity”, Journal of Experimental Psychology: Human Perception and Performance, Vol. 16 No. 2, pp. 391-397. Zuckerman M. ( 1991), Psychobiology of Personality, Cambridge: University Press. 
TABLES

Table 1 Influence of ingredient type and presence on product evaluation

\begin{tabular}{|c|c|c|c|c|c|}
\hline $\begin{array}{l}\text { Independent } \\
\text { Variables }\end{array}$ & Dependant Variables & $\begin{array}{c}\text { Mean } \\
\text { Level } 1\end{array}$ & $\begin{array}{c}\text { Mean } \\
\text { Level } 2\end{array}$ & $\mathrm{~F}$ & $\mathrm{P}$ \\
\hline \multirow{8}{*}{$\begin{array}{l}\text { Simple effect } \\
\text { Blackcurrant (1) / } \\
\text { Caramel (2) }\end{array}$} & $\begin{array}{l}\text { Pleasant to drink } \\
\text { (PLeasantness) }\end{array}$ & 3.04 & 2.63 & 18.773 & $0.000 * * *$ \\
\hline & Sickening (PL) & 2.97 & 3.54 & 25.543 & $0.000 * * *$ \\
\hline & Fruity taste (TAste) & 4.02 & 2.92 & 127.92 & $0.000 * * *$ \\
\hline & Disagreeable taste (TA) & 2.70 & 3.04 & 11.069 & 0.000 **** \\
\hline & Original color (Color) & 3.57 & 3.09 & 22.108 & $0.000 * * *$ \\
\hline & Distant color $(\mathrm{CO})$ & 3.84 & 3.16 & 45.435 & $0.000 * * *$ \\
\hline & Agreeable smell (SMell) & 3.04 & 2.85 & 4.643 & $0.032 * *$ \\
\hline & Special smell (SM) & 3.30 & 3.58 & 9.002 & $0.003 * *$ \\
\hline \multirow{8}{*}{$\begin{array}{l}\text { Simple effect } \\
\text { Absence (1) / } \\
\text { Presence (2) }\end{array}$} & $\begin{array}{l}\text { Pleasant to drink } \\
\text { (PLeasantness) }\end{array}$ & 2.72 & 2.92 & 4.204 & $0.041 * *$ \\
\hline & Sickening (PL) & 3.40 & 3.16 & 4.569 & $0.033 * *$ \\
\hline & Fruity taste (TAste) & 3.41 & 3.51 & 1.092 & 0.297 \\
\hline & Disagreeable taste (TA) & 2.96 & 2.81 & 2.122 & 0.146 \\
\hline & Original color (Color) & 3.31 & 3.34 & 0.062 & 0.803 \\
\hline & Distant color $(\mathrm{CO})$ & 3.57 & 3.43 & 1.705 & 0.192 \\
\hline & Agreeable smell (SMell) & 2.90 & 2.98 & 0.672 & 0.413 \\
\hline & Special smell (SM) & 3.38 & 3.50 & 1.671 & 0.197 \\
\hline
\end{tabular}


Table 2 Main Results

\begin{tabular}{|c|c|c|c|c|c|c|c|c|c|}
\hline $\begin{array}{l}\text { Independent } \\
\text { Variable } \\
\end{array}$ & Dependant Variable & $\begin{array}{l}\text { Sum of } \\
\text { squares }\end{array}$ & df & $\begin{array}{c}\text { Mean } \\
\text { Squares }\end{array}$ & $\mathrm{F}$ & $\mathrm{P}$ & $\begin{array}{c}\text { Mean } \\
\text { Level } 1\end{array}$ & $\begin{array}{c}\text { Mean } \\
\text { Level } 2 \\
\end{array}$ & $\begin{array}{c}\text { Mean } \\
\text { Level } 3\end{array}$ \\
\hline \multirow{9}{*}{$\begin{array}{l}\text { Cue } \\
\text { Label (1) / } \\
\text { Bottle (2) / } \\
\text { Can (3) }\end{array}$} & Pleasantness & 36.699 & 2 & 18.350 & 24.408 &, $000 * * *$ & 3.16 & 3.30 & 2.82 \\
\hline & Fruity Taste & 1.409 & 2 & .704 & .695 & .499 & 3.49 & 3.55 & 3.45 \\
\hline & Disagreeable Taste & 4.301 & 2 & 2.151 & 1.888 & .152 & 2.79 & 2.71 & 2.88 \\
\hline & Original Colour & 8.545 & 2 & 4.272 & 3.764 & $.024 * *$ & 3.48 & 3.57 & 3.33 \\
\hline & Distant Colour & 4.659 & 2 & 2.329 & 1.889 & .152 & 3.33 & 3.34 & 3.48 \\
\hline & Special Smell & 1.602 & 2 & .801 & .799 & .450 & 3.39 & 3.35 & 3.45 \\
\hline & Pleasant Smell & 29.598 & 2 & 14.799 & 17.107 & $.000 * * *$ & 3.25 & 3.40 & 2.96 \\
\hline & Original & 8.735 & 2 & 4.368 & 4.996 & $.007 * *$ & 4.08 & 3.99 & 3.84 \\
\hline & Mix originality & 7.937 & 2 & 3.969 & 3.809 & $.023 * *$ & 3.95 & 3.70 & 3.92 \\
\hline \multirow{9}{*}{$\begin{array}{l}\text { Absence (1) / } \\
\text { Presence (2) }\end{array}$} & Pleasantness & .120 & 1 & .120 & .159 & .690 & 3.08 & 3.10 & - \\
\hline & Fruity Taste & .787 & 1 & .787 & .776 & .379 & 3.53 & 3.47 & - \\
\hline & Disagreeable Taste & .969 & 1 & .969 & .851 & .357 & 2.83 & 2.76 & - \\
\hline & Original Colour & 1.405 & 1 & 1.405 & 1.238 & .266 & 3.41 & 3.50 & - \\
\hline & Distant Colour & .286 & 1 & .286 & .232 & .630 & 3.40 & 3.36 & - \\
\hline & Special Smell & .039 & 1 & .039 & .039 & .844 & 3.39 & 3.41 & - \\
\hline & Pleasant Smell & .385 & 1 & .385 & .445 & .505 & 3.18 & 3.23 & - \\
\hline & Original & .194 & 1 & .194 & .222 & .637 & 3.99 & 3.95 & - \\
\hline & Mix originality & .058 & 1 & .058 & .056 & .813 & 3.87 & 3.85 & - \\
\hline \multirow{9}{*}{$\begin{array}{l}\text { Aroma } \\
\text { Blackcurrant } \\
\text { (1) vs. } \\
\text { Caramel (2) }\end{array}$} & Pleasantness & 35.445 & 1 & 35.445 & 47.148 & $.000 * * *$ & 3.32 & 2.87 & - \\
\hline & Fruity Taste & 219.563 & 1 & 219.563 & 216.678 & $.000 * * *$ & 4.06 & 2.94 & - \\
\hline & Disagreeable Taste & 32.857 & 1 & 32.857 & 28.845 & $.000 * * *$ & 2.58 & 3.01 & - \\
\hline & Original Colour & 20.639 & 1 & 20.639 & 18.182 & $.000 * * *$ & 3.63 & 3.29 & - \\
\hline & Distant Colour & 106.697 & 1 & 106.697 & 86.541 & $.000 * * *$ & 3.77 & 2.99 & - \\
\hline & Special Smell & 6.530 & 1 & 6.530 & 6.514 & $.011 * *$ & 3.30 & 3.50 & - \\
\hline & Pleasant Smell & 18.959 & 1 & 18.959 & 21.916 & $.000 * * *$ & 3.36 & 3.04 & - \\
\hline & Original & 1.084 & 1 & 1.084 & 1.240 & .266 & 3.93 & 4.01 & - \\
\hline & Mix originality & .006 & 1 & .006 & .006 & .940 & 3.85 & 3.86 & - \\
\hline
\end{tabular}


Table 3

Interaction effects

\begin{tabular}{|c|c|c|c|c|c|}
\hline \multirow[t]{2}{*}{ Interaction Effect } & Variable 1 & $\begin{array}{c}\text { Variable } 2 \\
\text { Level } 1\end{array}$ & $\begin{array}{c}\text { Variable } 2 \\
\text { Level } 2\end{array}$ & \multirow[t]{2}{*}{$\mathrm{F}$} & \multirow[t]{2}{*}{$\mathrm{P}$} \\
\hline & Cue & Absence & Presence & & \\
\hline Pleasantness & $\begin{array}{c}\text { Label } \\
\text { Bottle } \\
\text { Can } \\
\end{array}$ & $\begin{array}{l}3.11 \\
3.39 \\
2.74 \\
\end{array}$ & $\begin{array}{l}3.20 \\
3.21 \\
2.90 \\
\end{array}$ & 2.631 & $.073 *$ \\
\hline Fruity Taste & $\begin{array}{c}\text { Label } \\
\text { Bottle } \\
\text { Can }\end{array}$ & $\begin{array}{l}3.35 \\
3.44 \\
3.27\end{array}$ & $\begin{array}{l}3.22 \\
3.26 \\
3.38\end{array}$ & 1.526 & .218 \\
\hline Disagreeable Taste & $\begin{array}{c}\text { Label } \\
\text { Bottle } \\
\text { Can }\end{array}$ & $\begin{array}{l}2.75 \\
2.37 \\
2.79 \\
\end{array}$ & $\begin{array}{l}2.39 \\
2.62 \\
2.70 \\
\end{array}$ & 3.891 & $.021 * *$ \\
\hline Original Colour & $\begin{array}{c}\text { Label } \\
\text { Bottle } \\
\text { Can } \\
\end{array}$ & $\begin{array}{l}3.05 \\
3.46 \\
3.16 \\
\end{array}$ & $\begin{array}{l}3.47 \\
3.24 \\
3.23 \\
\end{array}$ & 4.327 & $.014 * *$ \\
\hline Distant Colour & $\begin{array}{c}\text { Label } \\
\text { Bottle } \\
\text { Can }\end{array}$ & $\begin{array}{l}3.10 \\
3.13 \\
3.39\end{array}$ & $\begin{array}{l}3.11 \\
3.10 \\
3.29\end{array}$ & .339 & .712 \\
\hline Special Smell & $\begin{array}{c}\text { Label } \\
\text { Bottle } \\
\text { Can }\end{array}$ & $\begin{array}{l}3.44 \\
3.33 \\
3.41\end{array}$ & $\begin{array}{l}3.35 \\
3.37 \\
3.50\end{array}$ & .593 & .553 \\
\hline Pleasant Smell & $\begin{array}{c}\text { Label } \\
\text { Bottle } \\
\text { Can }\end{array}$ & $\begin{array}{l}3.15 \\
3.45 \\
2.94 \\
\end{array}$ & $\begin{array}{l}3.34 \\
3.35 \\
2.98 \\
\end{array}$ & 1.216 & .297 \\
\hline Original & $\begin{array}{c}\text { Label } \\
\text { Bottle } \\
\text { Can }\end{array}$ & $\begin{array}{l}3.79 \\
3.40 \\
3.66 \\
\end{array}$ & $\begin{array}{l}3.99 \\
3.60 \\
3.78 \\
\end{array}$ & 5.906 & $.003 * *$ \\
\hline Mix originality & $\begin{array}{c}\text { Label } \\
\text { Bottle } \\
\text { Can }\end{array}$ & $\begin{array}{l}3.87 \\
3.76 \\
3.96\end{array}$ & $\begin{array}{l}4.02 \\
3.64 \\
3.89\end{array}$ & 1.047 & .351 \\
\hline & Variable 1 & $\begin{array}{c}\text { Variable } 3 \\
\text { Level } 1 \\
\end{array}$ & $\begin{array}{c}\text { Variable } 3 \\
\text { Level } 2 \\
\end{array}$ & & \\
\hline & Cue & Blackcurrant & Caramel & & \\
\hline Pleasantness & $\begin{array}{c}\text { Label } \\
\text { Bottle } \\
\text { Can }\end{array}$ & $\begin{array}{l}3.28 \\
3.59 \\
3.07\end{array}$ & $\begin{array}{l}3.03 \\
3.01 \\
2.57\end{array}$ & 1.908 & .149 \\
\hline Fruity Taste & $\begin{array}{c}\text { Label } \\
\text { Bottle } \\
\text { Can }\end{array}$ & $\begin{array}{l}3.81 \\
3.99 \\
3.84\end{array}$ & $\begin{array}{l}2.76 \\
2.72 \\
2.81\end{array}$ & 1.072 & .343 \\
\hline Disagreeable Taste & $\begin{array}{c}\text { Label } \\
\text { Bottle } \\
\text { Can }\end{array}$ & $\begin{array}{l}2.41 \\
2.17 \\
2.58 \\
\end{array}$ & $\begin{array}{l}2.74 \\
2.82 \\
2.91 \\
\end{array}$ & 1.694 & .184 \\
\hline Original Colour & $\begin{array}{c}\text { Label } \\
\text { Bottle } \\
\text { Can } \\
\end{array}$ & $\begin{array}{l}3.58 \\
3.76 \\
3.54 \\
\end{array}$ & $\begin{array}{l}3.37 \\
3.37 \\
3.12 \\
\end{array}$ & .689 & .502 \\
\hline Distant Colour & $\begin{array}{c}\text { Label } \\
\text { Bottle } \\
\text { Can }\end{array}$ & $\begin{array}{l}3.83 \\
3.67 \\
3.82\end{array}$ & $\begin{array}{l}2.83 \\
3.01 \\
3.14\end{array}$ & 1.549 & .213 \\
\hline Special Smell & $\begin{array}{c}\text { Label } \\
\text { Bottle } \\
\text { Can } \\
\end{array}$ & $\begin{array}{l}3.35 \\
3.24 \\
3.31 \\
\end{array}$ & $\begin{array}{l}3.44 \\
3.45 \\
3.60 \\
\end{array}$ & 699 & .497 \\
\hline Pleasant Smell & $\begin{array}{c}\text { Label } \\
\text { Bottle } \\
\text { Can }\end{array}$ & $\begin{array}{l}3.42 \\
3.64 \\
3.04 \\
\end{array}$ & $\begin{array}{l}3.07 \\
3.16 \\
2.88 \\
\end{array}$ & 2.215 & .110 \\
\hline
\end{tabular}




\begin{tabular}{|c|c|c|c|c|c|}
\hline Original & $\begin{array}{c}\text { Label } \\
\text { Bottle } \\
\text { Can }\end{array}$ & $\begin{array}{l}3.963 \\
3.983 \\
3.845\end{array}$ & $\begin{array}{l}4.202 \\
3.990 \\
3.834\end{array}$ & 1.241 & .290 \\
\hline \multirow[t]{3}{*}{ Mix originality } & $\begin{array}{c}\text { Label } \\
\text { Bottle } \\
\text { Can }\end{array}$ & $\begin{array}{l}3.951 \\
3.794 \\
3.821\end{array}$ & $\begin{array}{l}3.947 \\
3.608 \\
4.029\end{array}$ & 2.714 & $.067 *$ \\
\hline & Variable 3 & $\begin{array}{c}\text { Variable } 2 \\
\text { Level } 1 \\
\end{array}$ & $\begin{array}{c}\text { Variable } 2 \\
\text { Level } 1 \\
\end{array}$ & & \\
\hline & Aroma & Absence & Presence & & \\
\hline Pleasantness & $\begin{array}{c}\text { Blackcurrant } \\
\text { Caramel }\end{array}$ & $\begin{array}{l}3.30 \\
2.96\end{array}$ & $\begin{array}{l}3.33 \\
2.88\end{array}$ & .009 & .924 \\
\hline Fruity Taste & $\begin{array}{c}\text { Blackcurrant } \\
\text { Caramel }\end{array}$ & $\begin{array}{l}4.09 \\
2.98\end{array}$ & $\begin{array}{l}4.03 \\
2.91\end{array}$ & .006 & .940 \\
\hline Disagreeable Taste & $\begin{array}{c}\text { Blackcurrant } \\
\text { Caramel }\end{array}$ & $\begin{array}{l}2.59 \\
3.07\end{array}$ & $\begin{array}{l}2.56 \\
2.95\end{array}$ & .307 & .580 \\
\hline Original Colour & $\begin{array}{c}\text { Blackcurrant } \\
\text { Caramel }\end{array}$ & $\begin{array}{l}3.64 \\
3.19\end{array}$ & $\begin{array}{l}3.62 \\
3.38\end{array}$ & 1.626 & .203 \\
\hline Distant Colour & $\begin{array}{c}\text { Blackcurrant } \\
\text { Caramel }\end{array}$ & $\begin{array}{l}3.85 \\
2.96\end{array}$ & $\begin{array}{l}3.70 \\
3.03\end{array}$ & 1.740 & .187 \\
\hline Special Smell & $\begin{array}{c}\text { Blackcurrant } \\
\text { Caramel }\end{array}$ & $\begin{array}{l}3.12 \\
3.37\end{array}$ & $\begin{array}{l}3.19 \\
3.33 \\
\end{array}$ & .469 & .493 \\
\hline Pleasant Smell & $\begin{array}{c}\text { Blackcurrant } \\
\text { Caramel }\end{array}$ & $\begin{array}{l}3.33 \\
3.02 \\
\end{array}$ & $\begin{array}{l}3.40 \\
3.05 \\
\end{array}$ & .053 & .818 \\
\hline Original & $\begin{array}{c}\text { Blackcurrant } \\
\text { Caramel }\end{array}$ & $\begin{array}{l}3.95 \\
4.02 \\
\end{array}$ & $\begin{array}{l}3.91 \\
3.99 \\
\end{array}$ & .001 & .975 \\
\hline Mix originality & $\begin{array}{c}\text { Blackcurrant } \\
\text { Caramel }\end{array}$ & $\begin{array}{l}3.84 \\
3.90 \\
\end{array}$ & $\begin{array}{l}3.87 \\
3.82 \\
\end{array}$ & .513 & .474 \\
\hline
\end{tabular}

* $0.1 \quad * * 0.05 * * * 0.01$ 
Study 1

Label of the aromatized cider

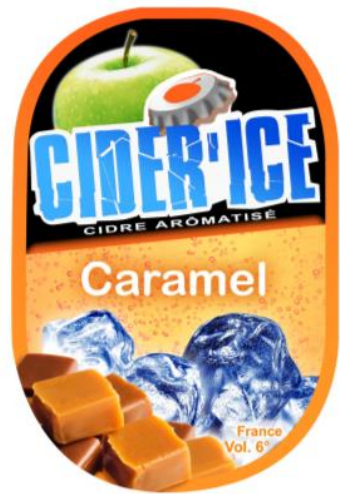

Atypical with image

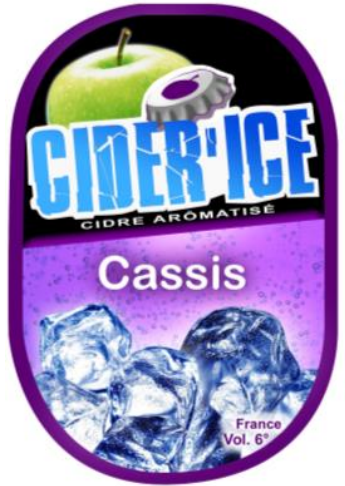

Typical without image
Study 2

Aromatized cider in can vs. bottle

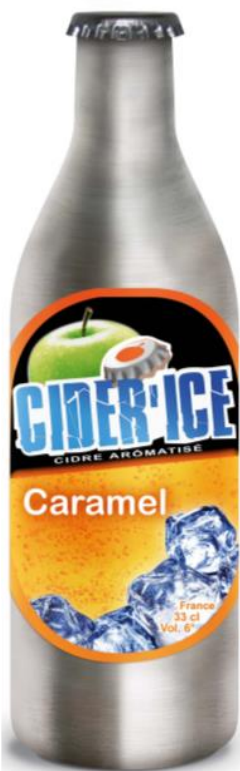

Bottle, Atypical, Without image

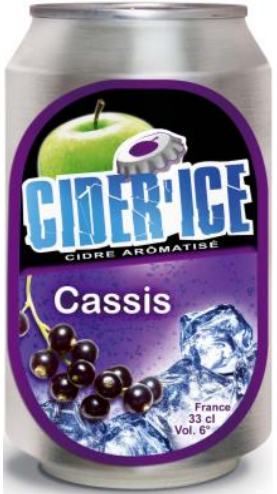

Can, Typical With image 
Appendix B. Significant interaction effects
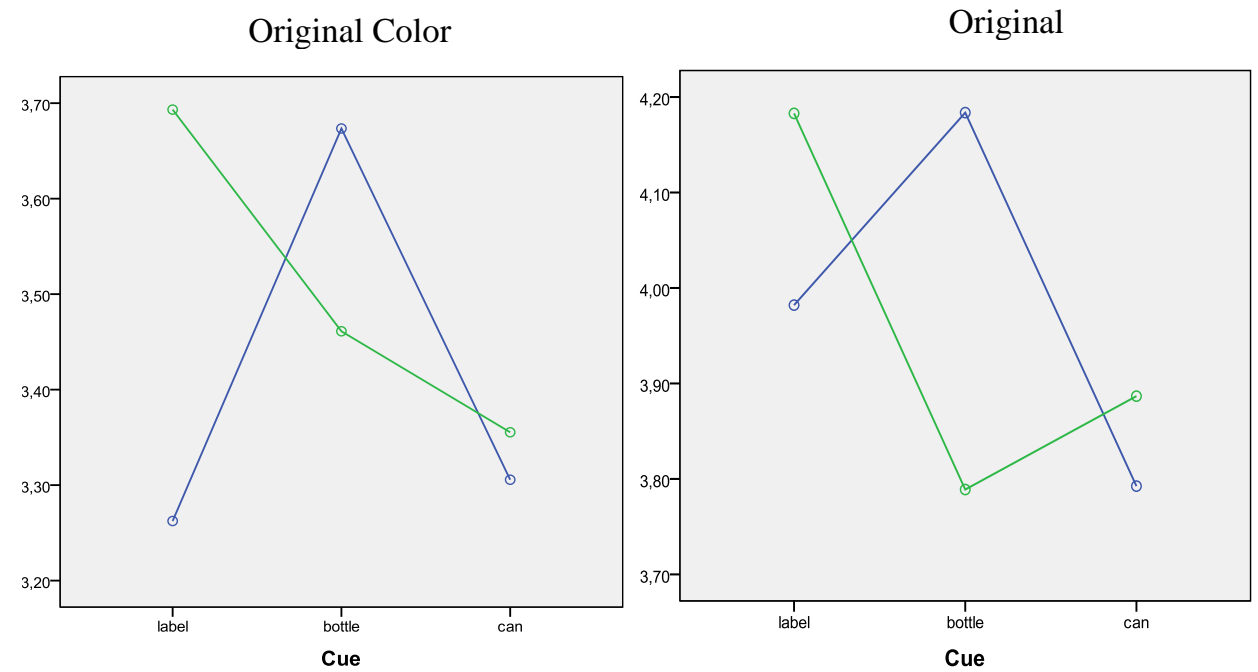

Abs vs.Pres

- absence

Pleasantness

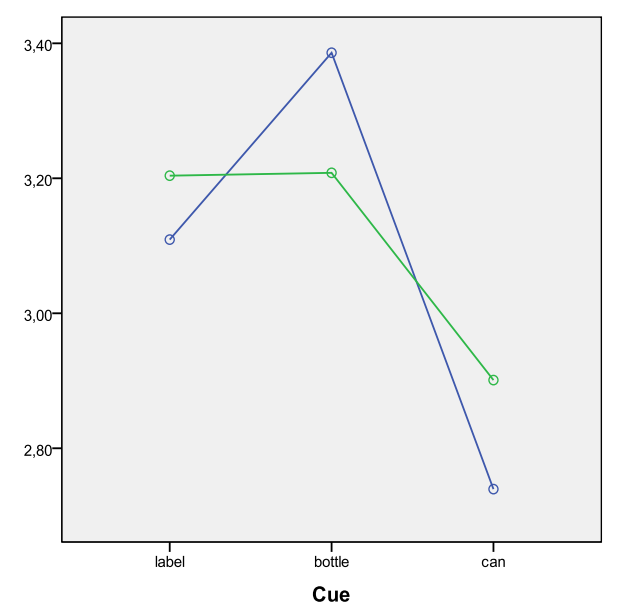

